\title{
Kepemimpinan Guru Kristen: Sebuah Tinjauan Etika Kristen
}

\author{
Giofany Junetri ${ }^{* 1}$, Yesaya Adhi Widjaya² \\ Universitas Pelita Harapan \\ *giofanyjunetri@gmail.com
}

DOI: https://doi.org/ 10.34307/b.v3i2.149

\begin{abstract}
The life in contemporary era is full of challenges that have a big impact to almost all aspects in society, including for the growth and development of students in school. Christian teachers should be a role model who keeps on equiping their competencies and grow spiritually in order to be able to lead students. Student in turn is expected to response properly with a true morality when facing all the challenges. Teaches leadership is prominent to be a model for the student to obtain a true morality. This paper will demonstrate the relationship or Christian teacher's leadership to the growth of student from the ethical perspectives. This paper will examine the essence or nature of Christian teacher, factors affecting, obstacles to Christian teacher leadership, and strategies that can be applied by Christian teacher. The true leadership model is Jesus who provides the meaning and example of leadership with humility within the purpose of God's Kingdom. By recognizing the true leadership of Jesus Christ, Christian teacher can help students to living out this life through the Christian ethics. This paper will also provide suggestions for further research which will included other aspects in education field.
\end{abstract}

Key Words: Christian teacher, students, leadership, perspective, ethic.

\begin{abstract}
Abstrak-Konteks kehidupan zaman ini dipenuhi dengan berbagai tantangan yang memiliki pengaruh yang besar hampir kepada semua aspek kehidupan masyarakat, khususnya bagi pertumbuhan dan perkembangan siswa-siswi di sekolah. Seorang guru Kristen sudah seharusnya menjadi seorang teladan yang secara konsisten menjaga kompetensi dan pertumbuhan spiritual sehingga mampu untuk memimpin siswanya. Siswa diharapkan akan menjadi seorang yang mampu menghadapi realitas hidup ini dengan respon dari moralitas yang benar. Guru adalah teladan pertama yang seharusnya memimpin murid untuk menyadari tentang moralitas yang benar. Makalah ini akan memaparkan kepemimpinan guru Kristen dalam hubungannya dengan pertumbuhan siswa yang ditinjau dari etika Kristen. Makalah ini berisi penjelasan tentang esensi dari natur sebagai seorang guru Kristen, faktor yang mempengaruhi, hambatan atau tantangan menjadi seorang guru Kristen, serta strategi yang bisa di aplikasikan oleh guru Kristen. Model kepemimpinan yang sejati adalah Yesus, yang menyediakan arti dan contoh kepemimpinan dengan kerendahatian dengan kerajaan Allah sebagai tujuannya. Mengakui Yesus sebagai pemimpin yang sejati, seharusnya membuat setiap guru Kriten menyadari untuk kemudian menolong siswanya untuk menghidupi hidup ini berdasarkan etika
\end{abstract}


Kristen. Makalah ini juga menyediakan saran untuk penelitiaan lebih jauh termasuk setiap aspek lingkungan Pendidikan.

Kata Kunci: Guru Kristen, peserta didik, kepemimpinan, perspektif, etika

\begin{tabular}{llll}
\hline Article History : & Received: 08-03-2020 & Revised: 25-08-2020 & Accepted: 13-12-2020
\end{tabular}

\section{Pendahuluan}

Dalam dunia pendidikan, khususnya dalam konteks kehidupan di sekolah, para siswa membutuhkan figur yang bukan hanya bisa mengajar mereka secara kognitif, tetapi juga figur yang mampu menuntun dan mengarahkan pertumbuhan kehidupan para siswa secara holistik. Menurut Gunadarsa dan Singgih, perkembangan anak pada tingkat SD (usia 6-12 tahun) adalah masa dimana perilaku anak dibentuk melalui penguatan, baik secara verbal, keteladanan ataupun suatu identifikasi.1 Lebih lanjut Gunadarsa dan Singgih menjelaskan bahwa pada masa ini anak-anak mulai membentuk suatu konsep, peran dan bagaimana sikap mereka terhadap lingkungan dimana mereka berada. Namun, fakta yang dapat disaksikan dilingkungan sekitar hari-hari ini adalah bahwa semakin meningkatnya teknologi, dalam hal media sosial dan internet, justru membuat para siswa seolah memperlihatkan tindakan yang tidak perduli terhadap situasi sekitarnya, terjadinya kemerosotan moral dalam banyak hal, dan pengabaian terhadap relasi dengan orang-orang sekitarnya2.

Fakta di atas sangat jauh dari natur siswa yang diharapkan, yakni pribadi yang mampu untuk belajar, mampu bekerjasama dengan pribadi lainnya, serta mampu untuk mencapai suatu prestasi. ${ }^{3}$ Signifikansi kepemimpinan seorang guru Kristen adalah mampu mengarahkan tindakan siswa yang menyimpang kepada tindakan yang benar. Penerapannya bisa dilakukan ketika pembelajaran di dalam kelas. Sebagai pemimpin, guru dalam hal ini juga perlu memperlihatkan ketegasan dalam menegur, serta hidupnya harus bisa menjadi teladan bagi para muridnya. ${ }^{4}$

Perilaku moral adalah salah satu studi etika yang mencari jawaban atas pertanyaan-pertanyaan seperti, "apa yang harus saya lakukan?", "apakah tindakan yang baik itu?", atau dengan kata lain studi etika adalah studi yang menyediakan nilai yang tepat untuk tindakan yang tepat. ${ }^{5}$ Nilai yang dimaksud adalah motif yang melatarbelakangi suatu tindakan yang dilakukan. Guru adalah pemimpin siswa di dalam kelas yang sudah seharusnya menyadari bahwa ia adalah pribadi yang diharapkan mampu untuk memberikan pengaruh yang benar terhadap siswa dengan cara menunjukkan perilaku hidup bermoral dari dirinya sendiri, sehingga dengan keteladanan yang guru Kristen berikan, akan menolong setiap murid untuk dapat menghadapi tantangan zaman ini dan meresponinya dengan benar.

${ }^{1}$ D. Gunarsa dan Yulia Singgih, Psikologi Praktis: Anak, Remaja, dan Keluarga (Jakarta: Gunung Mulia, 2004), 15.

2 Wilga Putri, Nunung Nurwati, and Meilanny Budiarti, "Pengaruh Media Sosial Terhadap Perilaku Remaja," Prosiding Penelitian Dan Pengabdian Kepada Masyarakat 3, no. 1 (2016): 136.

${ }^{3}$ Jane Bluestein, ed., Manajemen Kelas (Jakarta Barat: Indeks, 2013), 3.

4 Rahendra Maya, "Esensi Guru dalam Visi-Misi Pendidikan Karakter," Edukasi Islami 2, no. 3 (2013): 250.

${ }^{5}$ George R. Knight, Filsafat Dan Pendidikan (Jakarta: UPH Press, 2009), 9 
Guru Kristen sebagai seorang pemimpin harus menyadari bahwa siswa bukan hanya perlu diperlengkapi pada ranah kognitif saja, tetapi juga dalam perkembangan karakter yang sesuai dengan prinsip etika Kristen yang benar. Oleh karena itu, makalah ini bertujuan untuk mengkaji signifikansi kepemimpinan guru Kristen dan pengaruhnya terhadap pertumbuhan kehidupan siswa dari sudut pandang etika Kristen.

\section{Metode Penelitian}

Metode penelitian yang diterapkan pada makalah ini adalah metode penelitiaan literatur. Metode penelitian ini digunakan untuk mengumpulkan data ataupun fakta yang terjadi di lapangan berdasarkan sumber-sumber dari jurnal maupun tulisan ilmiah yang terpercaya dan akurat. Metode penelitian ini memberikan kemudahan bagi penulis untuk dapat meninjau sebuah fakta yang terjadi di lapangan tanpa harus terjun langsung ke lapangan. Metode ini membantu penulis dalam melihat dan membandingkan pendapat dari banyak penulis terkait topik atau tema yang diangkat dalam sebuah makalah atau karya ilmilah yang dituliskan.

\section{Natur Guru Kristen}

Guru Kristen bukan hanya sekadar guru yang beragama Kristen. Mengemban profesi sebagai guru Kristen berarti menunjukkan suatu tanggung jawab yang lebih besar daripada hanya sekadar nama atau gelar. Guru Kristen adalah pribadi yang diharapkan mampu untuk menjadi role model dan mentor yang mengarahkan murid dengan setia. ${ }^{6}$ Guru Kristen adalah seorang pribadi yang sudah lahir baru dan memiliki tanggung jawab untuk mengajarkan kebenaran kepada setiap anak murid. ${ }^{7}$ Lahir baru yang dimaksudkan adalah suatu kondisi atau keadaan dimana seseorang tersebut telah diberikan hati yang baru oleh karya Roh Kudus dan memampukan pribadi tersebut dapat mempercayai Injil. ${ }^{8}$ Tugas sebagai guru Kristen bukan hanya sekadar mempersiapkan pembelajaran dan mengajar, tetapi guru adalah sebagai alat yang dipakai Tuhan untuk menuntun para murid dan menjadikan mereka sebagai murid Tuhan.

Allah yang dalam kesempurnaan-Nya tetap memilih menyatakan kasih-Nya kepada manusia yang sebenarnya sangat berdosa dan membenci Allah. Allah menghendaki manusia dapat betul-betul merasakan dan menikmati kemuliaan Allah.9 Prinsip di atas dapat memberikan gambaran yang lebih besar bagaimana guru Kristen dapat menempatkan dirinya sebagai seorang pendidik, yakni seseorang membimbing dan mengarahkan anak didiknya untuk dapat melihat dan menikmati kemuliaan Tuhan di setiap aspek pembelajaran yang diberikan.

Tugas dari seorang guru adalah mendidik, mengarahkan, mengevaluasi dan memimpin peserta didik dengan menerapkan keahlian yang ia pelajari dari pendidikan

${ }^{6}$ James R. Estep, Michael J. Anthony, dan Gregg R. Allison, A Theology for Christian Education (USA: B\&H Publishing Group, 2008), 25.

7 Kiki Debora and Chandra Han, "Pentingnya Peranan Guru Kristen dalam Membentuk Karakter Siswa dalam Pendidikan Kristen: Sebuah Kajian Etika Kristen," Diligentia: Journal of Theology and Christian Education 2, no. 1 (January 2020): 9, https://doi.org/http://dx.doi.org/10.19166/dil.v2i1.2212.

${ }^{8}$ Grudem Wayne, Systematic Theology (USA: Inter-Varsity Press, 1994), hal 256.

${ }^{9}$ Jonathan Edwards, "Corcerning the End for Which God Created the World," Monergism, 1749,15 
profesi yang ia tempuh sebelumnya.10 Hal ini berarti guru mengemban tugas dan tanggung jawab yang besar karena siswa akan melihat contoh hidup dari seorang guru. Setiap guru Kristen perlu mengerti bahwa dengan perilaku dari seorang guru yang bertanggung jawab dapat mengarahkan pendidikan kepada situasi dimana setiap siswanya memiliki perilaku hidup benar dan terus bertumbuh. Salah satu tanggung jawab sebagai guru Kristen adalah bukan hanya sekadar memerhatikan murid sebatas kehidupannya di kelas saja, tetapi guru Kristen juga harus mampu merangkul kehidupan siswa di luar kelas, relasi dengan orang tua dan kehidupan pergaulannya.11

Penjelasan tentang hakikat menjadi seorang guru Kristen yang mengemban tugas sebagai suatu pelayanan, memberikan pemahaman bahwa tugas guru Kristen bukanlah suatu pilihan melainkan suatu kewajiban yang harus dilakukan oleh setiap orang yang Tuhan panggil. Ada banyak pilihan yang dapat ditemui oleh guru Kristen setiap kali melakukan suatu pembelajaran di dalam kelas. Memilih untuk melakukan pembelajaran yang didahului oleh persiapan sebelumnya, ataukah lebih memilih untuk sekadar mengajar dan menyelesaikan tugas sebagai guru semata. Guru Kristen seharusnya tidak menjadikan tugas mengajar sekadar sebagai menyelesaikan tugas saja karena jika demikian maka guru kristen tersebut melakukan ketidaksetiaan dan mengesampingkan kehendak Allah.12

\section{Kepemimpinan Guru Kristen}

Secara umum, kepemimpinan didefinisikan sebagai suatu kemampuan yang dimiliki oleh seseorang untuk dapat memotivasi perilaku para bawahan atau pengikutnya untuk mencapai suatu tujuan, mempengaruhi kelompok atau komunitas untuk suatu perbaikan dan perubahan13. Yesus dalam kehidupan-Nya selama di dunia ini memberikan suatu pemahaman yang besar tentang arti dari menjadi seorang pemimpin. Yohanes 13:1-15, memperlihatkan suatu contoh yang besar tentang tindakan seorang pemimpin yang melayani. Perkara ini bukan hanya sekadar tentang pembasuhan kaki semata tetapi merupakan bagian pelayanan kerendahan hati Yesus sebagai kesiapan menerima penderitaan yang ada di depan-Nya dan sebagai tindakan awal untuk membuat para murid melihat dan mengerti semua pekerjaan yang akan Yesus lakukan.

Yesus menekankan kepada para murid-Nya bahwa apa yang Ia lakukan haruslah dilakukan juga oleh para murid kepada orang lain. Pembasuhan kaki sebagai tanda mengambil bagian dalam pelayanan dengan Yesus harus juga dilakukan oleh murid-Nya untuk membawa setiap orang terlibat dalam pelayanan bersama dengan Yesus. Guru Kristen yang memimpin adalah guru Kristen yang siap untuk melayani, siap untuk diajar, dibekali dan disentuh hatinya. Kepemimpinan seorang guru Kristen dapat terlihat dari cara hidupnya yang meneladani Yesus, siap merendahkan hati untuk melayani semua orang yang dipercayakan kepadanya.

Pola kedua yang Yesus paparkan tentang kepemimpinan seorang guru Kristen adalah "memuridkan". Matius 4:19, memperlihatkan situasi dimana Yesus memanggil

10 Badrun Kartowagiran, "Kinerja Guru Profesional (Guru Pasca Sertifikasi)," Cakrawala Pendidikan 30, no. 3 (2011): 3455 .

${ }^{11}$ Abdul Hamid, "Guru Profesional," Al-Falah 17, no. 2 (2017): 8.

12 J. Van Dyk, Surat-Surat Untuk Lisa (Tangerang: UPH Press, 2013), 9.

13 Asep Solkin, Fatchurahman, and Supardi, "Pemimpinan Yang Melayani Dalam Membangun Bangsa Yang Mandiri," Anterior Jurnal 16, no. 2 (2017): 125. 
orang yang akan dijadikan murid-Nya dengan kata "Ikutlah Aku". Dalam hal ini Yesus mengajak mereka untuk turut "bersama" dan tidak membiarkan mereka sendiri ketika ia mengajak mereka menjadi murid-Nya. Kata-kata selanjutnya "kamu akan kujadikan penjala manusia", memberikan pemahaman bahwa Yesus tidak hanya sekadar memanggil, tetapi memberikan pernyataan tentang suatu tujuan yang mulia.14

Pola yang luar biasa ini juga perlu dimiliki oleh seorang guru Kristen yang memimpin. Guru Kristen akan menghadapi kemajemukan dari setiap anak didik di sekolah, khususnya kemajemukan nilai-nilai yang dianut siswa, tentang baik dan benar menurut mereka. Akan sangat berat untuk para guru Kristen memimpin para murid jika guru Kristen tidak memiliki pola yang jelas untuk menuntun mereka di tengah-tengah banyaknya perbedaan. Oleh karena itu guru Kristen harus yang terlebih dahulu menghidupi sikap hidup yang benar berdasarkan etika Kristen dan kemudian dapat menunjukkannya kepada setiap peserta didik.

Guru Kristen yang memimpin perlu melandaskan kepemimpinannya pada pola kepemimpinan yang mampu memberikan pertumbuhan dalam kehidupan para peserta didik. Pola yang dimaksudkan adalah pola yang mampu membuat para peserta didik menghadapi suatu makna atau value atau untuk kemudian dapat menempatkan suatu perilaku yang tepat dalam konteks hidup zaman sekarang ini.15 Ahiong memberikan beberapa ciri tentang pemimpin sejati yang dapat diterapkan oleh guru Kristen dalam kehidupan sebagai pemimpin di dalam kelas, yakni:16

\section{Ennoble (mengilhami)}

Dalam hal ini setiap pemimpin khususnya guru Kristen perlu mengajak para muridnya untuk mencapai keluhuran. Keluhuran yang dimaksudkan adalah suatu proses memaknai, menghargai nilai-nilai hidup yang benar, juga meliputi sikap menghargai dan menjaga martabat diri seseorang dan mengekspektasikan suatu pencapaian yang unggul dari murid-muridnya atau orang yang dipimpinnya.

\section{Enable (memampukan)}

Hal ini dimengerti sebagai suatu tindakan yang memampukan seseorang untuk diperlengkapi secara terus menerus dan membuatnya menjadi efektif dengan menyediakan alat, pengetahuan, perlengkapan, dan kemampuan yang diperlukan untuk melaksanakan suatu pekerjaan. Selain itu sikap memampukan ini berarti mampu mengembangkan nilai-nilai yang membuat seseorang dapat bertanggung jawab terhadap diri sendiri dan masa depannya.

\section{Empower (menguatkan)}

Kata menguatkan disini dapat dimengerti sebagai suatu tindakan seorang pemimpin yang mampu menguatkan atau memberdayakan sehingga seseorang dapat mengurangi atau tidak lagi terus-menerus bergantung pada orang lain. Seorang guru yang memimpin adalah seorang pribadi yang mampu menguatkan orang lain untuk menjalani hidup secara bertanggung jawab dan mandiri. Seorang guru Kristen perlu untuk mengerti nilai-nilai etika kristen dalam memutuskan suatu tindakan yang kemudian mengarahkan para muridnya pada suatu tujuan yang dimaksudkan. Hal ini tidaklah gampang, karena seorang guru Kristen yang memimpin adalah pribadi yang menggunakan kepemimpinan sebagai sarana untuk mengembangkan orang lain. Seringkali harus mengorbankan kepentingan diri sendiri. Kepemimpinan yang melayani

${ }^{14}$ Y. Ahiong, 10 Principles of Discipleship (Jakarta: Metanoia Publishing, 2012), 12.

${ }^{15}$ A \& Umiorso Wahab, Kepemimpinan Pendidikan dan Kecerdasan Spiritual (Yogyakarta, Indonesia: Ar-Ruzz Media, 2010), 65.

${ }^{16}$ Ahiong, 10 Principles of Discipleship, (Jakarta: Metanoia Publishing, 2012), 23. 
adalah percaya bahwa dirinya bukanlah yang terutama, mempergunakan kekuatan kejujuran, selalu mendengar dan peduli, melibatkan orang lain dan membantu mendapatkan suatu tujuan yang mulia.17

\section{Faktor Pengaruh Kepemimpinan Guru Kristen}

Ada banyak faktor yang memungkinkan pengaruh terhadap kualitas dari pada kepemimpinan seorang guru, baik dari dalam maupun dari luar. Usman mengatakan bahwa jiwa kepemimpinan adalah sesuatu yang dibawa sejak lahir dan tanpa melalui suatu pendidikan atau pelatihan seseorang tersebut sudah dapat menjadi pemimpin dalam bidangnya.18 Seorang guru Kristen harus mengerti bahwa tidak ada aspek dalam hidup ini yang tidak merupakan proses. Teori di atas bisa menjadi benar karena dapat disaksikan di sekitar kita bahwa ada orang-orang yang memang memiliki bakat-bakat kepemimpinan walaupun ia masih muda dan tidak memiliki gelar yang tinggi. Hal itu tidak bisa dibantah karena ada orang-orang tertentu yang memiliki karunia-karunia seperti demikian, namun perlu juga diperhatikan bahwa proses yang dijalani seseorang akan memperlihatkan bakat kepemimpinan. Sebagai seorang guru Kristen, kepemimpinan bukan dilihat dari seberapa hebat dia berkata-kata, namun dari kemampuannya mengatur kelas secara optimal, melaksanakan apa yang menjadi tanggung jawabnya secara total, berarti guru tersebut telah melaksanakan fungsinya sebagai pemimpin di kelas.19 faktor lain yang memengaruhi kepemimpinan adalah bagaimana seorang guru Kristen melihat tanggung jawabnya sebagai pemimpin di kelas dan tanggung jawab ini harus dipertanggungjawabkan kepada Tuhan.

Dengan pemahaman bahwa menjadi seorang guru Kristen adalah adalah suatu pertanggungjawaban di hadapan Tuhan, maka guru Kristen akan mampu untuk menunjukkan ataupun memberikan kinerja yang optimal. Ukuran kinerja inipun dapat dilihat dari bagaimana seorang guru Kristen ini menjalankan suatu amanah dengan profesi yang diembannya, memiliki rasa tanggung jawab terhadap pertumbuhan kehidupan peserta didik, dan memiliki kesetiaan dalam menjalankan tugasnya sebagai guru, baik di dalam kelas maupun di luar kelas.20 Faktor yang mampu memengaruhi kepemimpinan seorang guru dapat dilihat dari bagaimana cara guru tersebut memandang hakikat dan tujuan dari apa yang dikerjakannya. Kepemimpinan sebagai guru Kristen bukanlah sesuatu yang mudah, hal tersebut perlu terus dibangun diatas dasar pemikiran yang benar tentang tujuan dalam melakukan sesuatu. Hal inilah yang akan terus mendorong guru Kristen untuk terus mengembangkan diri dalam tugasnya sebagai seorang pemimpin di dalam kelas.

Kepemimpinan seorang guru Kristen adalah kepemimpinan yang dapat menciptakan manajemen kelas yang kondusif untuk belajar, efektif dan efisien. Hal ini dipengaruhi oleh faktor motivasi dari guru Kristen itu sendiri yang melakukannya bukan

\footnotetext{
17 Boanerges Siallagan, Panduan Pemimpin Untuk Memiliki Kepemimpinan (Indonesia: Garuda Mas Sejahtera, 2015), 115.

18 Husaini Usman, "Faktor-Faktor Yang Mempengaruhi Perilaku Kepala Sekolah," Jurnal Tenaga Kependidikan 2, no. 3 (2007): 15.

19 R Rahayu, R. \& Susanto, “Pengaruh Kepemimpinan Guru dan Keterampilan Manajemen Kelas terhadap Perilaku Belajar Siswa Kelas IV," Jurnal Pendidikan Dasar Perkasa: Jurnal Penelitian Pendidikan Dasar 4, no. 2 (2018): 225, https://doi.org/10.31932/jpdp.v4i2.178.

20 E Hasanah, D.S. Fattah, N. Prihatiin, "Pengaruh Pendidikan Latihan dan Iklim Kinerja terhadap Kinerja Guru Sekolah Dasar Se-Kecamatan Babakancikao Kabupaten Purwakarta," Jurnal Pendidikan dan Penelitian 11, no. 2 (2010), 54.
} 
untuk kepentingan diri sendiri tetapi untuk melakukan yang terbaik bagi siswanya.21 Pribadi yang sadar akan hakikat dari menjadi seorang pemimpin adalah pribadi yang betul-betul sadar bagaimana memperlakukan orang yang dipimpinnya. Guru Kristen perlu sadar akan hal ini, sehingga ia tidak hanya mengemban gelar sebagai guru Kristen, tetapi ia harus mengerti tugasnya sebagai pemimpin yang mengarahkan muridnya pada suatu tujuan yang mulia.

\section{Hambatan/Tantangan Kepemimpinan Guru Kristen}

Sama halnya dengan faktor yang memengaruhi perkembangan jiwa kepemimpinan, seorang guru Kristen juga tentunya berhadapan dengan berbagai hambatan atau tantangan dalam perjalanan pengembangan kepemimpinannya. Hambatan tersebut bisa menjadi hambatan yang berada dalam diri guru Kristen tersebut ataupun hambatan dari luar. Surbakti menjelaskan bahwa beberapa yang menjadi kendala seorang pemimpin Kristiani adalah adanya keakuan yang besar atau ego, keengganan untuk mengakui fakta-fakta tentang diri sendiri, enggan mengalami perubahan, kehilangan motivasi, visi dan misi yang buruk dan kompromi dengan kesalahan.22

Dalam kehidupan kepemimpinan guru Kristen, hal-hal seperti diatas merupakan suatu hal yang jelas akan dihadapi. Hal yang kemudian akan membedakan dengan pemimpin yang lain adalah bagaimana guru Kristen merespon itu sebagai suatu proses yang wajar. Guru kristen yang memimpin perlu percaya bahwa ada Roh Kudus yang akan terus memampukan orang percaya dalam melakukan setiap pelayanan 23 dalam hal ini khususnya sebagai seorang pemimpin di dalam kelas. Dengan demikian menjalani kehidupan sebagai seorang guru Kristen yang memimpin di dalam kelas akan menjadi suatu pengalaman yang luar biasa. Selain hambatan-hambatan di atas, guru perlu menyadari bahwa walaupun dirinya adalah seorang pemimpin di dalam kelas, guru Kristen juga tetap memiliki otoritas di atasnya, yakni kepala sekolah sebagai pemimpin tertinggi di sekolah. Kepala sekolah yang diharapkan adalah tentunya pribadi yang sepenuhnya bertanggung jawab akan jalannya proses administrasi di sekolah, penyedia pembinaan untuk meningkatkan kinerja tenaga pengajar dan banyak hal lagi.24

Hambatan bagi kepemimpinan seorang guru Kristen adalah jika guru Kristen tidak mendapatkan motivasi dari luar dirinya atau dari diri pemimpinnya sendiri, atau dalam hal ini, kepala sekolah tidak menjadi seorang pemimpin yang diinginkan oleh bawahannya. Oleh karena itu sudah seharusnyalah setiap pemimpin memiliki sikap hati yang selalu memberi diri untuk melihat apa yang menjadi kebutuhan dari anggota yang dipimpinnya. Dalam hal ini seorang kepala sekolah perlu sadar untuk terus memikirkan tentang pentingnya pelatihan atau seminar bagi para guru. Meskipun demikian perlu juga untuk mempertimbangkan keadaan kepala sekolah perihal kendala perkembangan kepemimpinan karena berdasarkan temuan penelitian, hambatan yang dihadapi kepala

${ }^{21}$ Fransiskus Jonet Prihandoko, "Hubungan Antara Motivasi Kerja dan Gaya Kepemimpinan Guru dengan Pengelolaan Kelas," Faktor Jurnal Ilmiah Kependidikan 5, no. 3 (2018): 135.

22 E.B Surbakti, Manajemen dan Kepemimpinan Hati Nurani (Jakarta, Indonesia: Gramedia, 2012), 133.

23 Wayne, Systematic Theology, 554.

24 Uray Iskandar, “Kepemimpinan Kepala Sekolah dalam Peningkatan Kinerja Guru," Jurnal Visi Ilmu Pendidikan 10, no. 1 (2013): 67. 
sekolah dalam penerapan kepemimpinan, bisa diakibatkan oleh kondisi geografis sekolah, bekal keilmuan, keadaan guru, dan tuntutan serta dukungan dari masyarakat.25

Hal yang kemudian dapat menjadi penghambat kepemimpinan adalah bahwa memang pemimpin memiliki peranan yang dominan dan peranan tersebut dapat memengaruhi moral kepuasaan kerja keamanan, kualitas kerja dan terutama tingkat prestasi.26 Guru Kristen perlu belajar bahwa puas terhadap hasil kerja bukanlah suatu masalah, tetapi yang menjadi masalah adalah berhenti hanya sampai tahap kepuasaan sesaat dan kemudian melupakan atau bahkan mengabaikan tanggung jawab besar di dalam posisi itu. Ada begitu banyak tantangan bagi kepemimpinan guru Kristen, baik faktor-faktor dari dalam dirinya maupun faktor yang berasal dari luar dirinya. Meskipun tantangan begitu banyak, seorang guru Kristen perlu mengerti bahwa dirinya sendiri tidak akan pernah bisa menghadapi hambatan-hambatan seperti demikian tanpa tuntutan Roh Kudus. Oleh karena itu, seorang guru Kristen perlu menyadari bahwa tantangan ataupun hambatan yang begitu rupa akan menjadi suatu proses hidup yang melatih seorang pemimpin untuk menjadi pemimpin yang sejati.

\section{Strategi Kepemimpinan Guru Kristen}

Sebagai pengikut Kristus, dalam mengemban tugas sebagai pemimpin di dalam kelas, guru Kristen perlu mengetahui bagaimana ia memperlakukan murid-murid yang dipercayakan Tuhan kepadanya. Buku Jesus Among Secular gods menjelaskan bahwa ketika seseorang mengerti pengajaran Yesus tentang bagaimana melihat arti dari menjadi seorang manusia, maka kemudian orang itu dikenal sebagai seorang yang memegang prinsip dan moral hidup27 Guru Kristen yang sadar akan keberadaan dirinya sebagai ciptaan yang telah jatuh dan telah ditebus, dapat kemudian mengembangkan dirinya dalam anugerah Tuhan untuk menjadi pemimpin yang membawa orang lain kepada Tuhan. Dengan pengertian yang benar tentang realitas hidup, guru memahami cara bertindak yang benar dan yang sesuai kehendak Tuhan.

Strategi mendasar yang perlu untuk dimiliki dan dilakukan oleh seorang guru Kristen adalah mengerti bagaimana harus membangun relasi yang baik dengan orang yang dipimpinnya. Relasi yang baik ini dapat diawali dengan suatu komunikasi yang baik kemudian mendiskusikan keputusan, menerapkan disiplin, melakukan pengawasan dan tentunya tidak lupa untuk terus memberikan motivasi.28 Strategi di atas adalah awal yang baik untuk membangun jiwa kepemimpinan yang diharapkan. Adapun hal-hal strategis yang kemudian tidak boleh dilupakan oleh seorang guru Kristen adalah bagaimana menjadi seorang guru yang profesional. Menjadi seorang guru yang profesional berarti mampu berkomitmen terhadap proses belajar siswanya, terus memperlengkapi diri dengan bahan ajar yang akan diajarkan, bertanggung jawab dalam

25 Imron A. Kusmintardjo Muhani, "Kepemimpinan Kepala Sekolah Dasar di Daerah Terpencil," Jurnal Pendidikan: Teori, Penelitian, Dan Pengembangan 1, no. 8 (2016): 122.

${ }^{26}$ N Triyatno, E. Anitah, S. \& Suryani, "Peran Kepemimpinan Kepala Sekolah Dalam Pemanfaatan

Media Pembelajaran Sebagai Upaya Peningkatan Kualitas Proses Pembelajaran," Jurnal Teknologi Pendidikan 1, no.2 (2013): 98.

${ }^{27}$ Ravi Zacharias dan Vitale Vince, Jesus Among Secular Gods (Tenggilis Mejoyo: Literatur Perkantas, 2018), 45.

28 Baharun Hasan, "Peningkatan Kompetensi Guru Melalui Sistem Kepemimpinan Kepala Madrasah," Jurnal Ilmu Tarbiyah 6, no. 1 (2018): 15. 
pengawasan hal belajar siswa melalui suatu evaluasi dan mampu menempatkan diri dalam segala situasi.29

Strategi selanjutnya yang perlu untuk guru Kristen terapkan sebagai seorang pemimpin adalah terus menerus belajar untuk mendisiplinkan diri sendiri. Seseorang tidak mungkin menjadi pemimpin yang mampu mendisiplinkan orang lain jika dirinya sendiri tidak ia disiplinkan. Disiplin merupakan sesuatu yang penting untuk menanamkan rasa hormat terhadap kewenangan.30 Dengan adanya self-discipline maka jiwa kepemimpinan akan dengan mudah dikembangkan. Pada dasarnya pemimpin adalah orang yang dapat dicontoh dari apa yang ia lakukan, tanpa berkata-kata pun, ia adalah seorang pemimpin dari tindakannya.

Menjadi seorang guru Kristen yang mampu memimpin dengan benar, perlu untuk terus memperlengkapi diri dengan wawasan dunia yang begitu luas. Artinya guru Kristen perlu untuk mengerti banyak hal tentang pengetahuan umum dan menjangkau jauh kemasa depan. Dengan pemikiran yang luas, maka kepemimpinan seorang guru Kristen adalah kepemimpinan yang dinyatakan sebagai suatu proses. Kepemimpinan itu berlangsung dalam kurun waktu cukup lama, memiliki suatu perencanaan yang matang, diorganisir dengan baik, mampu untuk melakukan pembimbingan, serta mampu melakukan pengawasan.31 Kepemimpinan guru Kristen bukanlah suatu hal yang mudah. Hal ini berbicara tentang waktu, proses dan komitmen, yang akan terus membentuk pribadi seorang pemimpin yang betul-betul mampu memimpin berdasarkan Etika Kristen yang benar.

\section{Pembahasan}

Secara umum, etika dimengerti sebagai salah satu bagian dari ilmu filsafat yang mempelajari tentang nilai kesusilaan, baik dan buruk, bukan mengenai fakta tetapi lebih kepada nilai-nilai moral32. Di dalam studi etika Kristen, suatu tindakan yang benar atau bermoral adalah tindakan yang keluar dari iman yang benar, berdasar kepada hukum Allah dan untuk kemuliaan Allah.33 Iman yang benar dimengerti sebagai suatu karya Roh Kudus yang membuat manusia mampu untuk percaya dan mengenal karya Penebusan oleh Yesus Kristus. Iman yang dimaksudkan juga adalah iman yang menunjukkan aspek perubahan dimana jiwa yang tadinya dikuasai oleh dosa sekarang berpaling kepada Kristus dan mengalami keterikatan yang kuat dengan-Nya. Suatu tindakan yang keluar dari Iman yang benar adalah tindakan yang dilakukan dengan suatu landasan kepercayaan kepada Tuhan Yesus sebagai Pribadi yang menghendaki perbuatan itu untuk dilakukan. Tidak hanya berhenti sampai disitu, tetapi tindakan yang didasari dengan iman adalah tindakan yang dilakukan sesuai dengan hukum Allah.

Pada dasarnya ketika manusia diciptakan, Allah sudah terlebih dahulu menuliskan hukum Allah dalam hati manusia. Hukum Allah yang dimaksudkan di sini adalah bahwa manusia pada naturnya tidak bisa menyangkali keberadaan Allah. Allah

${ }^{29}$ I Nengah Kusmaningtyas, Amiartuti. Sudja, "Pengaruh Kompetensi, Kepemimpinan Diri, Sistem Penghargaan, Lingkungan Kerja, terhadap Komitmen pada Profesi dan Profesionalisme Guru SMA Negeri di Bali," Jurnal Ilmu Ekonomi Dan Manajemen 9, no. 2 (2013): 102.

30 Vivi Rusmawati, "Peran Kepemimpinan Kepala Sekolah Dalam Upaya Meningkatkan Disiplin Kerja Guru Pada SDN 018 Balikpapan,” Ejournal Administrasi Negara 1, no. 2 (2013): 152.

31 Herawati Syamsul, "Penerapan Kepemimpinan Kepala Sekolah Dalam Meningkatkan Kinerja Guru Pada Jenjang Sekolah Menengah Pertama," Jurnal Manajemen Pendidikan 1, no. 2 (2017): 95, doi.org/10.24252/idaarah.vli2.4271.

32 Fahrul Siregar, “Etika Sebagai Filsafat Ilmu Pengetahuan,” De'Rechtsstaat 1, no. 1 (2015): 54.

${ }^{33}$ Ecumenical Creeds and Reformed Confessions (United States of America: CRC, 1988), 56. 
menghendaki manusia untuk melakukan kehendak Allah. Oleh karena itu manusia tidak dapat berdalih tentang apa yang menjadi tanggung jawabnya sebagai manusia yang diciptakan Allah.34 Kemudian jauh setelah manusia jatuh dalam dosa, kitab Keluaran 20:1-17 kembali menjelaskan Hukum Taurat tertulis sebagai ranah atau batasan yang Tuhan berikan bagi orang Israel dalam melakukan suatu tindakan yang benar bahkan dalam keberdosaan mereka. Kedatangan Yesus Kristus bukan berarti Hukum Taurat tidak berlaku lagi, namun memberikan suatu penegasan terhadap Hukum Taurat (Mat. 5:17) yang dimuat dalam hukum kasih (Mat. 22:37-39). Hal ini berarti setiap pengikutNya, gereja-Nya, atau guru Kristen, baik dalam pengakuannya, khotbah, dan pengajarannya harus memberikan tempat bagi Hukum Taurat serta Injil.35

Perilaku yang benar adalah tindakan yang dilakukan dengan tujuan memuliakan Allah. Segala sesuatu yang dilakukan haruslah sepenuhnya untuk kemuliaan Tuhan (Yoh. 3:30). Sebagai seorang guru Kristen perlu mengerti bahwa tindakannya dalam memimpin muridnya, baik ketika ia mengajar ataupun mempersiapkan pembelajaran adalah adalah suatu tindakan yang harus dilakukan dengan tujuannya memuliakan Tuhan. Dari ketiga hal di atas bukan berarti tindakan yang benar bisa dilakukan dalam 3 cara, melainkan ketiga hal di atas adalah satu kesatuan yang tidak terpisahkan, yakni, keluar dari Iman yang benar (out of faith), dilakukan sesuai ranah hukum Allah (Through God's Law) dan tentunya untuk kemuliaan Tuhan (for God's Glory).36

Ketika masih dibangku sekolah para murid adalah pribadi-pribadi yang sangat membutuhkan bekal untuk menghadapi realitas hidup di depan mereka terutama tentang etika hidup atau moralitas yang benar dalam membangun kehidupan mereka. Mereka perlu untuk diarahkan untuk hidup bersoasialisasi yang baik, tidak hanya berfokus kepada kehidupan disosial media. Penting bagi para murid untuk membangun relasi dengan teman ataupun lingkungan sekitar mereka. Mereka butuh suatu pondasi yang kuat untuk menjalani kehidupan ditengah perkembangan kehidupan yang begitu pesat seperti sekarang ini. Yesus telah menekankan bahwa orang yang mendengar perintah-Nya adalah orang yang membangun rumah di atas batu, suatu dasar yang kuat dan tidak mungkin tergoncangkan dan hal sebaliknya yang akan dialami oleh orang yang membangun rumah di atas pasir akan terlalu mudah untuk dihanyutkan oleh badai (Mat. 7:24-27).

Ahiong pada bagian fokus kajian memaparkan tentang 3 tugas guru yang memimpin, yakni Ennoble, Enable, Empower. Ennoble atau yang dapat dimengerti dengan kata mengilhami, maksudnya adalah setiap guru Kristen sebagai pemimpin perlu memastikan bahwa nilai kepemimpinan yang diberikan kepada muridnya bukan hanya sekedar suatu teori, tetapi merupakan praktek hidup yang nyata dalam kehidupan setiap hari. Contohnya adalah menghargai setiap perbedaan yang ada. Melihat perbedaan bukan sebagai suatu hal yang memisahkan, tetapi membantu murid untuk melihat perbedaan adalah keunikan dan sesuatu yang indah. Perbedaan merupakan suatu hal yang perlu untuk diapresiasi. Mengilhami juga dapat dimengerti sebagai sebuah cara untuk membantu murid melihat realitas dari perspektif yang benar, sehingga menghasilkan suatu motif serta tindakan yang benar pula. Hal inilah yang menjadi tanggung jawab guru Kristen sebagai pribadi yang memimpin.

\footnotetext{
${ }^{34}$ G.I. Williamson, Pengakuan Iman Westminster (Surabaya, Indonesia: Momentum, 2017), 69.

${ }^{35}$ Herman Bavinck, Our Reasonable Faith (Wm. B. Eerdmans, 1977), 156.

${ }^{36}$ Justin S. Holcomb, Know the Creeds and Councils (Grand Rapids: Zondervan, 2014), 35.
} 
Kedua, yaitu Enable. Enable atau memampukan disini berarti guru sebagai pemimpin bukan hanya memberikan suatu motivasi atau dorongan dari hanya sekedar berbicara. Guru perlu melakukan tindakan nyata. Tindakan nyata yang dimaksudkan adalah guru sebagai pemimpin perlu menolong muridnya dalam hal penyediaan fasilitas, bahan, atau alat yang diperlukan dalam proses pembelajaran. Hal ini bukan berarti guru perlu menyediakan fasilitas yang berlebihan. Contohnya adalah guru yang mengerti tentang kepemimpinan yang benar, akan mempersiapkan segala bahan ajar yang akan diajarkan kepada murid. Menyiapkan agenda yang rapi dan terstruktur untuk membuat kelas menjadi lebih kondusif. Selain itu guru juga bisa membuat suatu visualisasi dari materi yang akan diajarkan. Seperti contohnya menyiapkan power point jika fasilitas mendukung, atau setidaknya membuat suatu alat peraga. Menurut Van Brummelen dalam bukunya Berjalan Bersama Tuhan di dalam Kelas, jika seorang guru yang memimpin dapat dengan senang hati melakukan hal-hal tersebut, maka merekapun dapat disebut guru sebagai fasilitator37.

Ketiga, Empower. Empower atau menguatkan, memberikan kekuatan. Jika diharapkan sebagai pribadi yang memberikan kekuatan dan yang menguatkan orang lain, maka seorang guru Kristen haruslah merupakan seorang pribadi yang kuat dan memiliki mental yang kuat pula. Terkadang atau seringkali guru sebagai pemimpin harus mengorbankan ego ataupun kepentingan diri sendiri dalam hal menguatkan dan menolong muridnya menjadi seorang kuat. Menguatkan bukan berarti berpura-pura menjadi kuat, tetapi belajar untuk menjadi kuat melalui setiap proses yang ada untuk menguatkan orang lain. Seperti yang sudah dijelaskan pada fokus kajian di atas bahwa seorang guru kristen sebagai pemimpin harus memiliki pengertian bahwa dirinya bukanlah yang terutama, mempergunakan kekuatan kejujuran, selalu mendengar dan peduli, melibatkan orang lain dan membantu mendapatkan suatu tujuan yang mulia.38

Ketika Tuhan Yesus mendeklarasikan tentang Amanat Agung (Mat. 28:19-20), bukan berarti hal itu hanya berlaku pada bilangan murid Yesus pada zaman itu, tetapi amanat ini juga berlaku untuk semua pengikut Yesus, termasuk guru Kristen, yang saat ini diperhadapkan dengan begitu banyak tantangan imoralitas. Guru Kristen terpanggil sebagai gembala untuk menuntun setiap muridnya mengerti tentang etika hidup yang benar ataupun menggembalakan mereka untuk memiliki cara hidup bermoral di tengahtengah kerusakan moral zaman ini. Semua hal itu tentu dimulai dari cara hidup guru Kristen, ia juga haruslah pribadi yang mau dipimpin, belajar meneladani Yesus dan kemudian siap untuk memimpin orang lain.

Yesus dalam kepemimpinan-Nya Bersama-sama murid-murid-Nya, memberikan suatu prinsip kepemimpinan tentang pembasuhan kaki, yang memberikan pemahaman bahwa kepemimpinan yang sejati adalah kepemimpinan yang terus melayani dengan kerendahan hati. Seperti halnya dengan Rasul Paulus, seorang rasul yang hidup setelah Yesus naik ke sorga dan yang kemudian dikenal sebagai seorang pemimpin yang memiliki peran pelayanan yang luar biasa bahkan diantara para rasul lainnya. Rasul Paulus adalah seorang yang membangun kepemimpinannya dengan proses yang begitu panjang. Paulus menjalankan kepemimpinannya sebagai seorang pemimpin yang membangun pengetahuannya sendiri bahkan awalnya tanpa didampingi oleh rasul yang lain (Gal 1:11-24). Paulus bertanggung jawab dengan panggilan yang ia terima. Seorang guru Kristen akan mengerti bagaimana menjadi seorang pemimpin yang benar ketika ia

\footnotetext{
${ }^{37}$ Harro Van Brummelen, Berjalan Bersama Tuhan Di Dalam Kelas, 2nd ed. (Tangerang: Universitas Pelita Harapan Press, 2009), 65.

38 Siallagan, Panduan Pemimpin Untuk Memiliki Kepemimpinan (Jakarta: Garuda Mas Sejahtera), 115.
} 
meresponi panggilannya sebagai suatu hal yang harus dipertanggungjawabkan kepada Tuhan.

Dalam prosesnya, tentu guru sebagai pemimpin akan mengalami begitu banyak hambatan dan tantangan sebagaimana realitas kehidupan yang ada. Meskipun demikian, Allah menciptakan manusia itu sebagai seorang pribadi. Hal ini berarti manusia adalah pribadi yang mampu untuk membuat keputusan sendiri, mencapai suatu tujuan dan melangkah dengan arahan tujuan yang ia rencanakan. Pada faktanya, manusia adalah pribadi yang selalu bergantung kepada Sang pencipta.39 Guru Kristen tidak perlu takut terhadap tantangan dan hambatan tetapi percaya bahwa Yesus selalu ada dan akan selalu memberikan kelegaan (Mat. 11:28). Oleh karena itu, tidak ada alasan bagi seorang guru Kristen untuk tidak melakukan perintah Tuhan dalam memimpin setiap umat Tuhan yang dipercayakan kepada-Nya.

Dengan kesadaran bahwa Yesus turut bekerja (Kis. 8:28), guru Kristen akan melakukan yang terbaik dari dirinya untuk dapat menyenangkan Tuhan melalui cara hidupnya, setiap strategi yang direncanakan dan mempersiapkan diri sebaik mungkin untuk dapat menjadi pemimpin yang benar bagi anak didiknya. Dengan demikian kehidupan yang bermoral, yakni yang keluar dari iman yang benar, sesuai dengan hukum Tuhan dan untuk kemuliaan Tuhan, akan terpancar melalui kehidupan kepemimpinan guru Kristen, yang kemudian akan diteladani oleh murid-muridnya bahkan orang yang di sekitarnya.

Dewasa ini, sudah banyak terjadi isu-isu yang sangat memprihatinkan tentang tindakan ataupun reaksi-reaksi imoral yang ditunjukkan, baik dalam lingkungan sekolah ataupun lingkungan yang lebih luas. Hal ini terjadi karena terlalu banyak toleransi bagi tindakan amoral yang walaupun dalam hal yang sangat sederhana. Guru Kristen harus mempersiapkan diri untuk terus memimpin muridnya dan menyadarkan mereka tentang masalah seperti ini, dan hal ini juga harus dimulai dari tindakan yang sangat kecil atau sederhana.

Studi etika Kristen memberikan pelajaran bagaimana meneladani kehidupan Yesus yang sepenuhnya tidak bisa toleransi dengan tindakan-tindakan amoral, tetapi sebaliknya etika Kristen memberikan pemahaman untuk melihat kepada tindakan yang akan dilakukan dengan mengajukan pertanyaan-pertanyaan, "apakah hal ini memanifestasikan kekudusan Tuhan?", dan "bagaimana hal itu dapat membangun suatu komunitas yang dipanggil untuk hidup dalam kekudusan?" Lebih lanjut dijelaskan Rasul Paulus kepada jemaat di Tesalonika tentang perlunya pengajaran hidup etis. Pengajaran hidup etis adalah sikap hidup yang berpadanan dengan injil Kristus yang berkenan kepada Allah (1 Tes. 4:1), saling mengasihi, tidak bermalas-malasan, menjauhi percabulan, dan penyembahan berhala. Sikap hidup ini adalah sikap hidup yang tidak hanya sekali dilakukan tetapi adalah sikap hidup yang tidak pernah selesai. 40

Perkembangan kognitif dalam berbagai ilmu pengetahuan, teknologi, sosial dan aspek lainnya, merupakan suatu perkembangan hidup yang baik jika diiringi dengan sikap moral hidup yang baik dan benar dan terus bertumbuh. Siswa tidak bisa hanya terus berfokus kepada gawainya dan lupa tentang pentingnya menjalin suatu komunikasi dengan orang yang disebelahnya. Hal seperti ini terlihat begitu sederhana dan bukan menjadi masalah, tetap jika hal seperti ini terus ditoleransi, dampaknya akan

${ }^{39}$ Anthony Hoekema, Created in God's Image (USA: Wm. B. Eerdmans, 1986), 25.

40 Robert R. Boehlke, Sejarah Perkembangan Pikiran Dan Praktek Pendidikan, 4th ed. (Jakarta, Indonesia: Gunung Mulia, 2009), 51. 
menimbulkan tindakan-tindakan yang tidak peduli dan bahkan sampai kepada tindakan amoral.

Kepemimpinan guru Kristen sangat dibutuhkan dalam hal ini, dimana kepemimpinan yang mampu untuk membawa dan menuntun muridnya untuk memutuskan suatu tindakan yang bermoral berdasarkan etika Kristen. Oleh karena itu dengan melihat dari semua fokus kajian diatas maka dapat ditemukan bahwa Kepemimpinan guru Kristen adalah sesuatu yang harus terus dipelajari dan dikembangkan oleh seorang guru Kristen, dengan kata lain guru Kristen adalah pribadi yang secara terus menerus harus mampu untuk mendisiplinkan diri.41 Kepemimpinan guru Kristen yang sejati adalah melihat kepada teladan Yesus, yang dengan sepenuh hati menuntun murid-murid untuk percaya kepada-Nya. Sebagai seorang guru Kristen yang memimpin, hal inilah yang harus dimengerti sebagai suatu etika Kristen yang benar dan yang mengarahkan kepada moralitas yang benar.

Oleh karena itu dengan melihat dari pemaparan di atas maka adapun hal-hal yang dapat guru lakukan sebagai pemimpin dalam membantu muridnya menghadapi tantangan zaman ini yang tentunya dengan moraitas yang benar sesuai etika Kristen adalah:

Disiplin diri.

Ketika seorang guru memiliki disiplin diri yang baik dalam hal penggunaan gawai dan setiap media sosial yang digunakan, maka guru pun akan mampu memberikan teladan hidup yang baik bagi muridnya.

Memberikan pembelajaran yang kreatif.

Pembelajaran yang kreatif bisa dengan kegiatan-kegiatan kelompok. Hal ini dapat membantu siswa untuk memiliki dan menjalin relasi yang baik dengan orang lain, yang kemudian dapat berdampak kepada lingkungan sosial yang lebih luas.

Belajar Beradaptasi.

Guru perlu mengerti apa yang menjadi kebutuhan bagi para murid di masa seperti sekarang ini. Guru yang memimpin perlu untuk terus belajar mengembangkan diri, menambah wawasan yang baru dan luas terkait apa yang generasi seperti sekarang ini butuhkan. Dengan demikian guru dapat mendalami kehidupan anak muridnya dan membantu mereka untuk menghadapi tantangan-tantangan hidup yang mereka sedang hadapi.

\section{Kesimpulan}

Kepemimpinan guru Kristen adalah suatu kebutuhan bagi kehidupan para siswa. Setiap guru dapat mengarahkan siswanya moralitas yang benar berdasarkan etika Kristen. Seorang guru Kristen yang memimpin akan mampu mengarahkan siswa menanggapi dengan benar isu-isu kehidupan zaman ini. Oleh karena itu yang menjadi kesimpulan dari semua pemaparan di atas adalah kepemimpinan guru Kristen merupakan suatu keharusan untuk terus dikembangkan dan dilatih oleh setiap pribadi yang hendak menjadi guru ataupun yang sudah menjadi guru, baik dalam kehidupan pribadi maupun dalam kehidupan berkomunitas. Semua hal itu tentu harus dimulai dari kehidupan guru Kristen yang siap untuk diproses, menghadapi berbagai hambatan, tantangan, serta berbagai pergumulan. Semua hal yang bernilai tinggi selalu dimulai dari proses yang tidak mudah.

${ }^{41}$ Rusmawati, "Peran Kepemimpinan Kepala Sekolah Dalam Upaya Meningkatkan Disiplin Kerja Guru Pada SDN 018 Balikpapan," Jurnal Administrasi Negara 1, no. 2 (2013), 65. 


\section{Saran}

Dengan semua pemaparan di atas penulis sadar bahwa penelitiaan ini tentu memiliki kekurangan dalam banyak hal, oleh karena itu bagi penelitian selanjutnya akan lebih baik jika menggunakan data-data statistik yang dapat mengukur seberapa besar dampak yang diberikan terhadap kehidupan pendidikan dengan adanya pendidikan kepemimpinan guru sekarang ini. Tujuannya adalah untuk melihat keefektifan pendidikan ataupun pelatihan kepemimpinan guru yang banyak diberlakukan di sekolah-sekolah.

\section{Referensi}

Ahiong, Y. 10 Principles of Discipleship. Jakarta: Metanoia Publishing, 2012.

Bavinck, Herman. Our Reasonable Faith. Wm. B. Eerdmans, 1977.

Bluestein, Jane, ed. Manajemen Kelas. Jakarta Barat: Indeks, 2013.

Boehlke, Robert R. Sejarah Perkembangan Pikiran Dan Praktek Pendidikan. 4th ed. Jakarta, Indonesia: Gunung Mulia, 2009.

Brummelen, Harro Van. Berjalan Bersama Tuhan Di Dalam Kelas. 2nd ed. Tangerang: Universitas Pelita Harapan Press, 2009.

Debora, Kiki, and Chandra Han. "Pentingnya Peranan Guru Kristen Dalam Membentuk Karakter Siswa Dalam Pendidikan Kristen: Sebuah Kajian Etika Kristen.” Diligentia: Journal of Theology and Christian Education 2, no. 1 (January 2020): 1-12. https://doi.org/http://dx.doi.org/10.19166/dil.v2i1.2212.

Dyk, J. Van. Surat-Surat Untuk Lisa. Tangerang, Indonesia: UPH Press, 2013.

Ecumenical Creeds and Reformed Confessions. United States of America: CRC, 1988.

Edwards, Jonathan. "Corcerning the End for Which God Created the World." Monergism, 1749.

Estep, James R., Michael J. Anthony, and Gregg R. Allison. A Theology for Christian Education. USA: B\&H Publishing Group, 2008.

Hamid, Abdul. “Guru Profesional.” Al-Falah 17, no. 2 (2017): 1-12.

Hasan, Baharun. "Peningkatan Kompetensi Guru Melalui Sistem Kepemimpinan Kepala Madrasah." Jurnal Ilmu Tarbiyah 6, no. 1 (2018): 1-26.

Hasanah, D.S. Fattah, N. Prihatiin, E. "Pengaruh Pendidikan Latihan Dan Iklim Kinerja Terhadap Kinerja Guru Sekolah Dasar Se-Kecamatan Babakancikao Kabupaten Purwakarta." Jurnal Pendidikan Dan Penelitian 11, no. 2 (2010).

Hoekema, Anthony. Created in God's Image. USA: Wm. B. Eerdmans, 1986.

Holcomb, Justin S. Know the Creeds and Councils. Grand Rapids: Zondervan, 2014. https://www.scribd.com/book/213641299/Know-the-Creeds-and-Councils.

Iskandar, Uray. "Kepemimpinan Kepala Sekolah Dalam Peningkatan Kinerja Guru." Jurnal Visi Ilmu Pendidikan 10, no. 1 (2013): 1018-27. 
Kartowagiran, Badrun. "Kinerja Guru Profesional (Guru Pasca Sertifikasi)." Cakrawala Pendidikan 30, no. 3 (2011): 463-73.

Knight, George R. Filsafat Dan Pendidikan. Jakarta: UPH Press, 2009.

Kusmaningtyas, Amiartuti. Sudja, I Nengah. "Pengaruh Kompetensi, Kepemimpinan Diri, Sistem Penghargaan, Lingkungan Kerja, Terhadap Komitmen Pada Profesi Dan Profesionalisme Guru SMA Negeri Di Bali." Jurnal Ilmu Ekonomi Dan Manajemen 9, no. 2 (2013): 94-102.

Maya, Rahendra. "Esensi Guru Dalam Visi-Misi Pendidikan Karakter." Edukasi Islami 2, no. 3 (2013): 281-96.

Muhani, Imron A. Kusmintardjo. "Kepemimpinan Kepala Sekolah Dasar Di Daerah Terpencil." Jurnal Pendidikan: Teori, Penelitian, Dan Pengembangan 1, no. 8 (2016): 1464-72.

Prihandoko, Fransiskus Jonet. "Hubungan Antara Motivasi Kerja Dan Gaya Kepemimpinan Guru Dengan Pengelolaan Kelas." Faktor Jurnal Ilmiah Kependidikan 5, no. 3 (2018): 275-90.

Putri, Wilga, Nunung Nurwati, and Meilanny Budiarti. "Pengaruh Media Sosial Terhadap Perilaku Remaja.” Prosiding Penelitian Dan Pengabdian Kepada Masyarakat 3, no. 1 (2016): 47-154.

Rahayu, R. \& Susanto, R. "Pengaruh Kepemimpinan Guru Dan Keterampilan Manajemen Kelas Terhadap Perilaku Belajar Siswa Kelas IV." Jurnal Pendidikan Dasar Perkasa: Jurnal Penelitian Pendidikan Dasar 4, no. 2 (2018): 220-29. https://doi.org/10.31932/jpdp.v4i2.178.

Rusmawati, Vivi. "Peran Kepemimpinan Kepala Sekolah Dalam Upaya Meningkatkan Disiplin Kerja Guru Pada SDN 018 Balikpapan.” Jurnal Administrasi Negara 1, no. 2 (2013): 1-256.

Siallagan, Boanerges. Panduan Pemimpin Untuk Memiliki Kepemimpinan. Indonesia: Garuda Mas Sejahtera, 2015.

Singgih, D. Gunarsa \& Yulia. Psikologi Praktis: Anak, Remaja, Dan Keluarga. Jakarta, Indonesia: Gunung Mulia, 2004.

Siregar, Fahrul. "Etika Sebagai Filsafat Ilmu Pengetahuan." De'Rechtsstaat 1, no. 1 (2015): 54-61.

Solkin, Asep, Fatchurahman, and Supardi. "Pemimpinan Yang Melayani Dalam Membangun Bangsa Yang Mandiri.” Anterior Jurnal 16, no. 2 (2017): 90-103.

Surbakti, E.B. Manajemen Dan Kepemimpinan Hati Nurani. Jakarta, Indonesia: Gramedia, 2012.

Syamsul, Herawati. "Penerapan Kepemimpinan Kepala Sekolah Dalam Meningkatkan Kinerja Guru Pada Jenjang Sekolah Menengah Pertama." Jurnal Manajemen Pendidikan 1, no. 2 (2017): 275-89. https://doi.org/10.24252/idaarah.vli2.4271.

Triyatno, E. Anitah, S. \& Suryani, N. "Peran Kepemimpinan Kepala Sekolah Dalam Pemanfaatan Media Pembelajaran Sebagai Upaya Peningkatan Kualitas Proses Pembelajaran." Jurnal Teknologi Pendidikan 1, no. 2 (2013): 226-38. 
Usman, Husaini. “Faktor-Faktor Yang Mempengaruhi Perilaku Kepala Sekolah.” Jurnal Tenaga Kependidikan 2, no. 3 (2007): 1-18.

Wahab, A \& Umiorso. Kepemimpinan Pendidikan Dan Kecerdasan Spiritual. Yogyakarta, Indonesia: Ar-Ruzz Media, 2010.

Wayne, Grudem. Systematic Theology. USA: Inter-Varsity Press, 1994.

Williamson, G.I. Pengakuan Iman Westminster. Surabaya, Indonesia: Momentum, 2017.

Zacharias, Ravi, and Vitale Vince. Jesus Among Secular Gods. Tenggilis Mejoyo: Literatur Perkantas, 2018. 